\title{
Evangelikal: Jurnal Teologi Injili dan Pembinaan Warga Jemaat
}

ISSN 2548-7868 (print), 2548-7558 (online)

Availabel at https://journal.sttsimpson.ac.id/index.php/EJTI/

DOI: https://doi.org/10.46445/ejti.v5i2.393

\section{Church Education Strategies in Overcoming Syncretism in the Dayak Tribe of Punan Lisum}

\author{
Sona Jhon", Gideon², Mikha Agus Widiyanto ${ }^{3}$ \\ Sekolah Tinggi Teologi Tenggarong, Kalimantan Timur, Indonesia \\ Email: ${ }^{1}$ sonna.jhon99@gmail.com, ${ }^{2}$ ungaugideon@gmail.com, ${ }^{3}$ mikha.agus08@gmail.com
}

\begin{abstract}
This research aims to find the appropriate strategy in overcoming syncretism in the lives of the Dayak Punan Lisum tribe so that their faith grows in the proper knowledge according to the Gospel. This research was conducted on the community in Muara Belinau Village, Tabang Districts, Kutai Kartanegata District, East Kalimantan. This study uses a qualitative approach with ethnographic methods. Data collection was carried out using interviews. The results showed that the Dayak Punan Lisum Christians in Muara Belianu Village still believed in particular objects considered to have power from God. Even though they have become Christians for decades, they still hold on to their old beliefs. This research shows syncretism in the Dayak Punan Lisum community. However, teaching, preaching, pastoral counseling,discipleship, and involvement in prayer groupspositively changed faith beliefs from old beliefs to Christian beliefs. In addition, faith-building in society reduced syncretism in the life of confidence in the Dayak Punan Lisum tribe.
\end{abstract}

Key Words:Strategy, Overcoming, Syncretism, Life of Faith

\begin{abstract}
ABSTRAK:Tujuan penelitian untuk menemukan strategi yang tepat dalam upaya penanggulangan sinkretisme dalam kehidupan Suku Dayak Punan Lisum agar iman percayanya bertumbuh dalam pengetahuan yang benar sesuai dengan Injil. Penelitian ini dilakukan pada masyarakat di Desa Muara Belinau, Kecamatan Tabang, Kabupaten Kutai Kartanegata, Kalimantan Timur. Penelitian ini menggunakan pendekatan kualitatif dengan metode etnografi. Pengumpulan data dilakukan dengan menggunakan wawancara, pengamatan dan kuesioner. Hasil penelitian menunjukkan bahwa orang Kristen Suku Dayak Punan Lisum di Desa Muara Belianu masih memercayai pada benda-benda tertentu yang dianggap memiliki kuasa dari pada Tuhan. Meskipun telah menjadi Kristen sudah usia puluhan tahun, namun masih berpegang pada kepercayaan lama mereka. Penelitian ini menunjukkan adanya sinkretisme dalam masyarakat Suku Dayak Punan Lisum. Melalui pengajaran, kotbah, konseling pastoral dan pemuridan serta kelompok doa memberikan kontribusi yang positif dalam perubahan kepercayaan iman dari kepercayaan lama kepada kepercayaan iman Kristen. Pembinaan iman di tengah-tengah masyarakat mampu mengurangi sinkretisme dalam kehidupan iman percaya Suku Dayak Punan Lisum.
\end{abstract}

Kata Kunci: Strategi, Penanggulangan, Sinkretisme, Kehidupan Iman

Article History: Submitted: 26 Maret 2021

Revised: 8 Mei 2021

Published: 28 Juli 2021

\section{PENDAHULUAN}

Kehidupan masyarakat di daerah pedalaman ketika adanya peralihan kepercayaan atau iman. Kecenderungannya masih terdapat pencampuran antara kepercayaan iman lamanya dengan kepercayaan iman baru yang dianutnya. Pencampuran kepercayaan ini yang dinamakan sinkretisme. Sinkretisme menjadi persoalan yang menjadi perhatian dalam pemberitaan ajaran dan pembinaan iman Kristen (Mulyadi, 2019). Dilihat dari aspek epistemologi, maka sinkretisme memiliki konotasi positif, karena mengandung makna harmonisasi dari dua perspektif berbeda yang menjadi satu (Singgih, 2000). Asimilasi dalam masyarakat sosial memang tidak dapat dihindari. Menurut Koentjaraningrat (2002) bahwa sebagai bagian dari proses sosial, dimana adanya interaksi yang intens 
dari latar belakang kebudayaan dan kepercayaan. Pergaulan yang lama di tengah masyarakat sosial membuat sinkretisme antara kebudayaan bahkan kepercayaan iman tidak dapat dihindari.

Namun apabila dilihat dari sisi iman Kristen, maka sinkretisme memiliki konotasi negatif, karena peleburan nilai-nilai dari asimilasi yang seringkali bertentangan dengan kepercayaan iman Kristen. Tentunya tidak mudah mengubah kebudayaan yang telah mengakar dalam diri masyarakat, sehingga kecenderungan dalam pelayanan pemberitaan Injil masih ditemukan bercampurnya nilai kebudayaan dalam implementasi iman Kristen (Talan, 2019). Menurut Kobong (2012) dalam hubungan antara kebudayaan dengan Injil tidak dapat dihindari terjadinya dua kutub yang berlawanan, yaitu resistensi atau penolakan dan asimilasi. Penolakan terjadi dikarenakan pemahaman bahwa Injil sebagai kebenaran mutlak yang tidak bisa diintervensi dan terkontaminasi oleh apapun yang berbeda dengan isi kebenaran Injil itu sendiri. Penolakan ini diartikan sebagai bagian dari upaya mencoba menghindari terkontaminasinya Injil dan menjaga kemurniannya. Sedangkan dari asimilasi, kebudayaan dipersepsikan secara positif sehingga memungkinkan terjadinya asimilasi (Kobong, 2012). Pada pandangan kedua diperkuat oleh pernyataan Cahyadi (2010) bahwa kebudayaan tidak bisa diubah oleh Injil, satusatunya jalan yang dapat dilakukan de-ngan asimilasi. Asimilasi ini yang memberi peluang terjadinya sinkretisme, sehingga menjadi persoalan dalam implementasi pembinaan iman bagi orang percaya. Memang adanya budaya tertentu yang bisa diterima karena tidak bertentangan dengan berita Injil. Namun tidak bisa dipungkiri bahwa adanya budaya tidak semuanya selaras dengan Injil. Adanya nilai-nilai budaya bertolakbelakang dengan Injil yang membuat asimilasi menyebabkan terjadinya sinkretisme, sehingga berdampak pada iman percaya bagi kelompok orang percaya tersebut. Menurut Tanuwidjaja dan Udau (2020) bahwa fakta ditemukan banyak terjadi kerancuan dalam menyikapi perkembangan budaya. Ada yang harusnya dihilangkan karena bertolak belakang dengan Injil namun dipertahankan, namun sebalik- nya ada yang harusnya dipertahankan tetapi dibuang. Alasan-alasan dalam melestarikan budaya lokal kadangkala menjadi penyebab terjadinya sinkretisme.

Problematika sinkretisme ini yang juga terjadi di kalangan masyarakat Dayak Punan Lisum di Desa Muara Belinau sebagai salah satu dari sekian banyaknya sub Suku Dayak Punan yang ada di Kalimantan Timur. Budaya yang dianut di kalangan masyarakat Dayak Punan Lisum masih melekat dalam kehidupan sehari-harinya. Masih ada sebagian orang yang memercayai mitos-mitos yang tidak sesuai dengan Injil. Dimana mereka menggunakan benda-benda dari cerita nenek moyang dahulu yang dianggap dapat melindungi atau mengusir roh-roh jahat. Praktik itu masih dilakukan sampai sekarang walaupun mereka juga sudah menjadi orang percaya atau Kristen. Ada pula yang masih mengandalkan dukun dengan percaya bahwa dukun dapat membantu Tuhan dalam menolongnya. Nilai-nilai dalam budaya yang masih melekat dalam kepercayaan sehari-hari, sehingga berpengaruh dalam pertumbuhan imannya.

Masalah dalam penelitian ini dirumuskan sebagai berikut: Pertama, bagaimanakah bentuk sinkretisme dalam kehidupan iman percaya Suku Dayak Punan Lisum? Kedua, bagaimanakah strategi penanggulangan sinkretisme dalam kehidupan iman percaya Suku Dayak Punan Lisum? Tujuan penelitian ini untuk menemukan strategi yang tepat dalam upaya penanggulangan sinkretisme dalam kehidupan Suku Dayak Punan Lisum di Desa Muara Belinau agar iman percayanya bertumbuh dalam pengetahuan yang benar sesuai dengan Injil.

\section{METODE}

Penelitian ini menggunakan pendekatan kualitatif dengan metode etnografi. Menurut Spradley (1979) bahwa dalam penelitian etnografi pada intinya berupaya memperhatikan tindakan atau perilaku dari suatu kejadian dengan memberikan makna-makna atasnya dalam upaya untuk memahaminya. Penelitian ini dilakukan pada masyarakat di Desa Muara Belinau, Kecamatan Tabang, Kabupaten Kutai Kartanegara, Kalimantan Timur. Teknik pengumpulan data 
menggunakan wawancara dan pengamatan dan kuesioner. Analisis data dalam penelitian ini dilakukan dari mulai proses pengumpulan dengan menggunakan analisis deskriptif, yaitu dengan mendeskripsikan sikap, perilaku dan yang dipercayai oleh masyarakat Suku Dayak Punan Lisum sebagaimana yang dimaknainya, kemudian melakukan analiais berdasarkan konteks iman Kristen.

Upaya dalam penanggulangan dari sinkretisme iman percaya dalam kehidupan masyarakat Suku Dayak Punan Lisum, dilakukan kajian secara kepustakaan dan melalui upaya gereja dalam pembinaan yang dilakukannya. Dalam penelitian ini dilakukan pengumpulan data melalui wawancara dan kuesioner untuk melihat keefektifan strategi yang dilakukan gereja dalam pembinaan iman percaya kepada Suku Dayak Punan Lisum.

\section{HASIL DAN PEMBAHASAN}

\section{Profil Suku Dayak Lisum}

Suku Dayak Punan Lisum berasal dari Negara Malaysia yaitu dari Tanah Bayu. Suku Dayak Punan Lisum mulai berpindah-pindah dengan alasan karena terjadi penjajahan, tepatnya di daerah Apau Kayan, di Desa Long Nawang yang dekat dengan perbatasan Indonesia dengan Malaysia. Suku Dayak Punan Lisum setelah tahun 1945 keluar dari hutan melalui Sungai Boh ke Nyatuq di pedalaman di Desa Long Lebusan.

Kehidupan Punan Lisum di Nyatuq masih erat dengan adat istiadat (masih ada penggal kepala) yang pada saat itu di bawah pimpinan Loping lalu dilanjutkan oleh Jaget (yang disebut pada saat itu sebagai Kepala Dusun). Setelah sekian lama, banyaknya yang meninggal ketika berada di Nyatuq sehingga Punan Lisum harus berpindah ke (Sungai Huq) yaitu di Temaru. Pada saat itu Injil sudah mulai masuk dalam kalangan Punan Lisum yang dibawakan oleh Pendeta Ungau kemudian banyak yang dibaptis di Muara Long Top. Kemudian, sejak pada saat itu kebaktian sudah berjalan dalam kalangan Punan Li- sum yang dilanjutkan oleh Pendeta Jalung lalu Pendeta Bawe.

Suku Punan Lisum telah lama menjadi Kristen, yaitu sajak tahun 1953. Pendeta Ungau sejak dari tahun 1953 telah memasuki Daerah Apau Kayan dan membaptis orang-orang di Temaru yang khususnya Suku Dayak Punan Lisum. Temaru adalah salah satu tempat Suku Punan Lisum berpindah setelah dari Nyatuq, dan lokasi Temaru tidak jauh dari Desa Long Top yang pada saat ini tempat Suku Dayak Punan Lisum menetap.(Pdt. Ungau, 2020)

\section{Praktik-Praktik Sinkretisme Di Kalangan Punan Lisum}

\section{Darau}

Darau ini adalah bahasa Punan Lisum, darau (kulit kayu) diambil dari kulit pohon tertentu lalu dikeringkan. Darau (kulit pohon) tidak asing lagi dalam kalangan Punan Lisum, bahkan darau (kulit pohon) bisa dibawa kemana-mana ketika bepergian, bahkan ada juga yang menyimpan di rumah sebagai stok atau untuk berjaga-jaga untuk digunakan ketika dibutuhkan. Menurut Petemay (2020) bahwa mereka memercayai Darau itu untuk mengusir hantu, karena dapat melindungi bagi yang menggunakannya. Dengan cara dibakar, bisa juga diambil arangnya digosokkan pada bagian tubuh, seperti tanda salib, khususnya kepada orang sakit agar tidak (semohon)". Semohon adalah bahasa Punan Lisum menyebut orang yang kerasukan. Darau digunakan dapat melindungi seseorang agar tidak kerasukan roh jahat. Darau (kulit pohon) dipercayai mempunyai kuasa untuk melindungi bahkan dengan mengoles membuat tanda salib.

Marlena (2020), Inoq (2020), Beny (2020) dan Wenci (2020) mengatakan bahwa darau (kulit pohon) itu untuk mengusir hantu agar hantu tidak akan berani mendekat. Darau dipercayai dengan maknanya agar membuat hantu takut. Ketika cuaca buruk difungsikan agar hantu tidak berani untuk mengganggu, juga ketika anak kecil menangis tanpa henti sehingga dapat digosok di badan sang bayi. 
Dalam pandangan Suku Punan Lisum bahwa darau dianggap memiliki kuasa dalam mengusir hantu dibandingkan dengan Tuhan, sehingga mereka lebih memercayai darau dibandingkan dengan Tuhan.

Pandangan ini yang terus dipercaya meskipun usia kekristenan di tengah-tengah masyarakat sudah begitu lama. Injil yang telah diajarkan belum sepenuhnya mengakar dalam pandangan mereka yang membuatnya tetap percaya akan kepercayaan sebelum menjadi Kristen. Iman percaya mereka belum menunjukkan sesuai dengan Injil dan belum tertanam dengan kokohnya. Menurut Warren (1992) bahwa apabila setan berhasil membuat seseorang buta terhadap Allah, maka setan tersebut telah berhasil mengambil berkat yang telah Tuhan rencanakan. Kepercayaan terhadap darau, akan membuat iman percaya di kalangan Suku Dayak Punan Lisum belum sepenuhnya sesuai dengan rencana dan kehendak Allah. Tentunya iman ini memengaruhi kehidupan mereka dalam aktivitas kesehariannya dan tidak lagi hidup mengandalkan serta percaya pada kuasa Tuhan. Darau sebagai benda mati yang sesungguhnya tidak memiliki kuasa. Hanya Tuhan yang memiliki kuasa atas kehidupan manusia dan alam semesta.

\section{Bulu Sengangang}

Bulu sengangang merupakan bahasa Punan Lisum yang istilah ini menunjuk pada bulu binatang. Ukurannya tidak begitu besar sehingga mudah dibawa kemana-mana. Bulu sengangang juga sering disimpan dalam dompet agar mudah dibawa, khususnya dibawa jika bepergian ke hutan untuk bekerja. Bulu sengangang itu kita gunakan untuk mengusir hantu dan juga bisa digunakan ketika cuaca buruk. Dengan dibakar pada saat cuaca buruk akan dapat menghentikan cuaca tersebut. Bulu sengangang dipercayai lebih kuat dibandingan dengan darau untuk mengusir cuaca buruk. Darau dianggap dapat membuat setan marah, sehingga dengan menggunakan Bulu sengangang membuat setan akan takut. Bulu sengangang dianggap lebih memiliki kuasa dibandingkan dengan darau.(Away, 2020; Beny, 2020; Marlena, 2020; Noriati, 2020; Wenci, 2020).
Kepercayaan yang dimiliki orang Dayak Punan Lisum menunjukkan bahwa mereka lebih percaya pada bulu binatang dari pada Kuasa Tuhan. Bulu binatang lebih dipercayai memiliki kuasa yang dapat menjaga dan melindungi mereka dari cuaca dan situasi buruk. Sesungguhnya Tuhanlah yang lebih berkuasa dan dapat mengubah keadaan atau cuaca yang buruk seperti peristiwa Tuhan Yesus meredakan angin ribut (Mrk. 4:39) Tuhan adalah Pencipta alam semesta yang Mahakuasa. Allah yang berkuasa untuk menghentikan cuaca, bukan manusia dengan menggunakan benda-benda mati yang dianggap memiliki kekuatan gaib. Kuasa Allah lebih besar dari kuasa apapun yang ada di dalam dunia ini (Gawa, 2020).

\section{Dang}

Dang dalam bahasa Punan Lisum yang ditujukan untuk bulan setengah atau bulan sabit. Dang sangat mempengaruhi dalam kehidupan mereka khususnya dalam beraktivitas mengerjakan sesuatu. Misalnya ketika ingin membangun rumah, maka tidak diperkenankan ketika bulan dang. Apabila membangun rumah pada bulan dang dapat menyebabkan di daerah dapur mudah terbakar, sehingga akan merambat pada keseluruhan bagian rumah (Petemay, 2020). Bahkan tukang bangunan yang ada juga tidak mau mengerjakan pembangunan rumah pada bulan ini. Mereka memercayai bahwa akan berakibat bencana, rumah terasa panas sehingga mudah terbakar juga akan membuat sakit. Artinya membangun rumah di bulan dang akan mendatangkan kesialan dalam kehidupan bagi yang tinggal di dalam rumah tersebut (Beny, 2020; Marlena, 2020; Wenci, 2020; Yusuf, 2020). Kepercayaan ini terjadi turun-temurun, dari generasi ke genarasi. Yang tertanam sangat kuat sampai generasi sekarang, sehingga membuat masyarakat Suku Dayak Punan Lisum takut membangun rumah di saat bukan sabit (dang). Kebakaran rumah tentunya tidak ada korelasinya dengan bulan sabit. Faktor penyebab kebakaran dipengaruhi banyak hal, bisa karena kelalaian manusia seperti lupa mematikan kompor, korsleting listrik, atau lupa mematikan api pun- 
tung rokok dan sebagainya. (Yendri, Wildian, \& Tiffany, 2017)

\section{Salit atau Uwen}

Salit atau Uwen dalam bahasa Suku Punan Lisum artinya angin kencang atau dapat dikatakan cuaca buruk. Istilah ini sering digunakan ketika menertawakan binatang sehingga menyebabkan terjadinya cuaca buruk. Binatang apapun apabila menunjukkan perilaku lucu dan ada yang menertawakan maka akan berakibat buruk, sehingga adanya larangan bagi masyarakat Suku Punan Lisum untuk membuat binatang menjadi bahan candaan. Bahkan untuk binatang seperti cacing atau lainnya pun dilarang menertawakan karena akan mengakibatkan (salit atau uwen) yang artinya cuaca yang buruk, angin yang kencang bahkan bisa petir menyambar orang yang menertawakan binatang tersebut (Beny, 2020; Petemay, 2020; Wenci, 2020). Bahkan menurut Yusuf (2020) dalam cerita nenek moyang adanya raja binatang, apabila menertawakan binatang dapat menyebabkan seseorang terlilit batu yang disebut salit atau uwen. Bahkan menertawakan kepiting, siput dapat membuat terjadinya hujan batu (Wenci, 2020). Salit atau Uwen menurut masyarakat Suku Punan Lisum sebagai suatu kenyataan yang mereka yakini pernah terjadi (Marlena, 2020).

Salit atau uwen sebagai suatu kepercayaan di kalangan Suku Dayak Punan Lisum merupakan mitos-mitos dari nenek moyang sebagai larangan untuk berbuat yang konyol. Keyakinan bahwa fenomena ini pernah terjadi yang menjadikan mereka terus memegang kepercayaan ini turun-temurun yang menjadi cerita dari generasi ke generasi. Tentunya peristiwa seperti cuaca buruk atau angin kencang ataupun petir sebagai fenomena alam bukan karena disebabkan seseorang menertawakan binatang. Menurut March et al. (2019) bahwa hujan deras, angin kencang merupakan fenomena squall yang dihasilkan karena awan cumulunimbus. Kejadian hujan deras, angin kencang bahkan petir yang terjadi pada masyarakat Suku Dayak Punan Lisum bisa saja merupakan fenomena squal yang disebabkan oleh awan cumulonimbus, bukan faktor mentertawakan binatang.

\section{Petalo}

Petalo dalam bahasa Suku Dayak Punan Lisum menunjuk pada tindakan seseorang yang mempunyai kekuatan khusus dalam menyembuhkan orang yang sakit. Petalo dianggap membantu Tuhan untuk menyembuhkan seseorang yang sakit. Masyarakat memercayai adanya orang-orang tertentu yang memiliki ilmu yang terlahir dari keturunan, yang memiliki kemampuan khusus menyembuhkan orang sakit dengan menggunakan batu-batu tertentu. Batu itu diperoleh melalui penglihatan dari mimpi, dimana hantu yang menunjukkan batu yang digunakan dan memperkenalkan pemiliknya dahulu. Ini dianggap bertujuan baik untuk kesembuhan tanpa menggunakan mantra atau bacaan tertentu, sehingga orang yang mendapatkannya tetap baik-baik saja dan dapat mengikuti ibadah gereja (Away, 2020).

Menurut Beny(Beny, 2020) bahwa petalo adalah berdukun, dimana dukun tersebut dianggap dapat melihat penyakit seseorang dan menyembuhkannya. Petalo dilakukan dengan duduk. Yusuf (2020) mengatakan bahwa Petalo untuk melihat kesehatan seseorang ketika sakit, tetapi dokter tidak mengetahui jenis penyakitnya, sehingga petalo dapat melihat apakah itu memang suatu penyakit atau di kirim oleh ilmu lain (dukun lain). Melalui petalo dapat melihat dengan memastikan kesehatan seseorang dan menyembuhkannya melaluikekuatan gaib (Marlena, 2020). Bagi masyarakat Suku Dayak Punan Lisum petalo bukanlah sesuatu yang salah. Petolo justru membantu Tuhan dalam menyembuhkan seseorang, secara khusus ketika dokter secara medis tidak bisa memastikan jenis penyakit dan menyembuhkannya. Parktik semacam ini tentunya sangat bertentangan dalam iman Kristen. Tuhan perlu penolong manusia justru bertolak belakang dengan berita Injil. Bukan manusia yang berkuasa untuk memberi kesembuhan bagi orang sakit melainkan justru Tuhan yang memiliki kuasa untuk menyembuhkan. Dalam iman Kristen justru petalo tidaklah dibenarkan. 1 
Timotius 4:1 dinyatakan bahwa inilah adalah roh penyesat dan ajaran setan. Petalo tentunya suatu penyesatan yang menggunakan tipu daya dan disebut sebagai pendusta. Perdukunan dalam Alkitab sangat jelas dilarang (Kel. 22:18-20; Ul. 18:9-13, Yes. 8:1920; 1 Sam. 28:3,9). Praktik perdukunan mendatangkan murka Allah karena dianggap sebagai dosa besar (Yes. 19:3-4). Erich (2007) menyatakan bahwa Iblis dan roh-roh jahatnya menyebarkan ajarannya dengan menggunakan tipu daya. Tipu daya Iblis yang digunakan dan berhasil sampai sekarang ini dengan melakukan penyamarannya sebagai malaikat terang. Iblis melakukannya dengan tipu daya, salah satunya melalui perdukunan yang dianggap membantu Allah untuk menolong manusia. Allah Mahakuasa menunjukkan kuasa-Nya yang tidak terbatas dan melebihi kuasa apapun (Gawa, 2020). Menurut Rick (1986) bahwa tenung merupakan sihir dengan menggunakan benda-benda sebagai sarana pelepasan kuasa supraalami dari Iblis. Biasanya mengunakan jimat, benda keramat, berhala, ramuan pekasih, atau benda yang diminum. Praktik ini bagian dari perdukunan. Melibatkan diri dalam pekerjaan Iblis adalah suatu kekejian dan kejijikan bagi Allah (Erich, 2007).

\section{Parit}

Parit dalam bahasa Dayak Suku Punan Lisum menunjuk pada arti kualat. Parit (kualat) menunjuk pada seseorang yang terdampak mengalami sesuatu yang kurang baik karena perbuatannya yang tidak menghormati orang yang lebih tua. Orang yang menyia-nyiakan dan tidak menghormati orang lebih tua, akan mendapatkan parit dimana dirinya tidak akan berhasil dalam bekerja dan menjadi orang yang tidak dihargai (Away, 2020; Beny, 2020). Sikap parit ini yang bisa ditunjukkan dengan membentak. Orang yang serakah juga akan mengalami parit. Akibatnya parit ini bisa berbentuk ambeien dan buncit perut (Marlena, 2020). Parit dianggap berdampak yang buruk bagi seseorang dalam menjalani kehidupannya (Yusuf, 2020).

Sikap atau perilaku yang tidak menghargai orang lebih tua, tentunya secara sosial akan berdam- pak pada penghargaan orang lain terhadap dirinya. Bahkan perilaku yang kurang menghargai orang lebih tua akan menyebabkan seseorang tidak disukai dan relasinya dengan orang lain menjadi kurang baik, sehingga berdampak pada keberhasilan dalam bekerja atau lainnya. Perilaku generasi yang tidak menghargai orang lebih tua, kehilangan norma-norma, tata krama, pemberontak dan terkikisnya nilai-nilai agama disebabkan karena kurangnya pembimbingan yang dilakukan secara terus menerus (Tong, 2000).

Perilaku tersebut bisa saja terjadi dikarenakan kurangnya peran orang tua dalam memberikan bimbingan secara kontinu dan gereja dalam melakukan peran pengajaran dan pendidikan nilai iman Kristen. Orang tua memiliki tugas dan tanggung jawab menanamkan nilai-nilai iman Kristen kepada anaknya. Apabila dalam masa pertumbuhan-nya hingga anak menjadi dewasa, belum bertumbuh secara rohani dengan memiliki pengertian, pemahaman dan perwujudan iman yang kokoh di mana masih kurang menghargai orang tua dan memerlakukannya buruk, maka orang tua belum melakukan fungsi dan perannya dengan baik. (Berkhof \& Van Til, 2010)

Apabila perilaku tidak menghargai orang tua yang dianggap dapat berdampak menjadi penyakit ambeien atau perut menjadi buncit tentunya belum menunjukkan adanya korelasi yang signifikan. Ambeien dapat disebabkan pembengkakan pembuluh darah vena. Hal ini akibatnya meningkatkan tekanan directum bagian bawah yang disebabkan buang air besar, duduk terlalu lama, kelebihan berat badan, hingga kurang asupan berserat. Resiko penyebab ambeien seperti kehamilan, sembelit kronis, duduk terlalu lama, juga faktor usia (Jevi Nugraha, 2020). Dengan demikian, ambeien secara medis bukan disebabkan seseorang tidak menghargai orang lebih tua, namun faktor lainnya.

\section{Tengen}

Tengen sebagai istilah dalam Bahasa Suku Dayak Punan Lisum, yang artinya kepohonan. Makna dari kepohonan ialah akibat dari sesuatu yang tidak dicapai atau dilakukan. Sehingga, orang yang disebut 
tengen (kepohonan) mendapatkan akibat atau bencana dalam melakukan perjalanan atau berpergian karena sebelumnya ingin memakan sesuatu tetapi tidak kesampaian. Misalnya seseorang yang ingin berpergian dan sebelumnya ingin meminum atau memakan sesuatu, namun sampai yang bersangkutan pergi melakukan perjalanan belum tersampai keinginannya. Ini akan berakibat seperti dipatuk ular, sesat dan kejadian yang membahayakannya. (Beny, 2020; Petemay, 2020). Menurut Marlena (2020) bahwa tengen dapat berdampak yang sangat buruk sampai pada kematian. Menurut Yusuf tengen (kepohonan) memang mitos tetapi dipercayai sebagai kenyataan dalam menjalani kehidupan sampai sekarang ini. Kuasa doa dianggap tidak akan mampu melindungi seseorang yang tengen (Wenci, 2020).

Kepohonan (tengen) menjadi kekeliruan dan tidak sejalan dengan konsep iman Kristen. Kepercayaan ini menunjukkan bahwa seseorang meragukan kuasa Allah dalam memberikan perlindungan-Nya dari segala bahaya. Mazmur 46:1-11 bahwa Allah tempat perlindungan dan kota benteng yang memberikan perlindungan bagi umat-Nya. Mazmur 121:7 dinyatakan bahwa "Tuhan akan menjaga engkau terhadap segala kecelakaan; Ia akan menjaga nyawamu." Kata "menjaga" terjemahan dari kata dalam

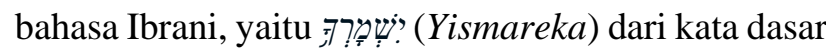
שֵָׁ (shamar), yang artinya to keep (menjaga). Tuhan yang menjaga dan melindungi umat-Nya di manapun dan dalam aktivitas apapun.

\section{Ngoek}

Ngoek dalam Suku Dayak Punan Lisum artinya bersiul yang memiliki makna bahwa ketika seseorang bersiul di malam akan berdampak yang buruk, dimana hantu akan membalikkan atau menarik lidahnya (Away, 2020; Beny, 2020; Wenci, 2020; Yusuf, 2020). Ngoek di malam hari adalah mengundang roh-roh jahat untuk datang mendekati, sehingga dilarang (Marlena, 2020). Ngoek ini masih dipercayai dalam kalangan Punan Lisum, yang ceritanya dari turun temurun nenek moyang dahulu, dimana mereka memercayai hantu yang bekerja dibalik semua itu.
Suku Dayak Punan Lisum memercayai takhayul sebagaimana yang diistilahkan dengan ngoek. Erich (2007) menyatakan bahwa percaya terhadap takhayul tidak berakal sehat yang tidak bisa dipercaya kebenarannya. Takhayul bersumber dari kepercayaan nenek moyang atau leluhur yang bersal dari ajaran kepercayaan tertentu. Takhayul merupakan penyesatan yang tidak bisa diterima kebenaran secara iman Kristen.

\section{Petulang}

Petulang dalam Bahasa Suku Dayak Punan Lisum diartikan dua orang dalam satu rumah ketika ingin bepergian jauh atau usaha dan bekerja. Maknanya adalah mempunyai akibat jika terjadi petulang dalam kehidupan dua orang tersebut dalam pekerjaan maupun usaha mereka, berkat tidak akan lancar dalam pekerjaan dan usaha mereka. Petulang tidak baik, karena akan memberikan hasil yang tidak baik saat bekerja, seperti sakit, justru menjadi penghalang dalam bekerja (Away, 2020).

Menurut Beny (2020) bahwa petulang tidak bisa dilanggar oleh masyarakat Suku Dayak Punan Lisum karena akan memberikan akibat bagi orangorang yang bertolak belakang dengan kepercayaan ini. Orang yang sama-sama bepergian dalam satu hari dari satu rumah, akan ada saja sesuatu yang buruk akan terjadi, akan mengakibatkan sial dalam perjalanan. Marlena (2020) menyatakan bahwa pasti ada saja diantara salah satu dari kedua orang yang petulang itu mengalami musibah dalam perjalanan bahkan usahanya tidak akan berhasil.

\section{Kejolok}

Kejolok dalam bahasa Suku Dayak Punan Lisum diartikan seseorang yang sedang pergi berburu ditanyai kemana atau ketika berburu disediakan bumbunya terlebih dahulu. Maknanya bahwa ketika seseorang yang berburu ditanyai ingin kemana atau menyiapkan bumbunya terlebih dahulu maka akan memberikan kesialan dan tidak akan memberikan hasil (Away, 2020; Beny, 2020). Terjadinya kejolok karena pertanyaan seseorang yang membuat sial 
dalam hasil perburuan seseorang, bahkan seseorang yang berencana ikut berburu kemudian membatalkan juga berdampak pada kesialan (Marlena, 2020; Wenci, 2020). Pertanyaan seseorang tentang hendak pergi kemana ataupun menyiapkan bumbu sebelum berburu tentunya tidak ada kaitannya dengan keberhasilan seseorang berburu. Keberhasilan seseorang dalam konteks iman Kristen mengacu pada memercayakan seluruh hidup dan aktivitasnya kepada Tuhan dan mengandalkan-Nya dalam mengerjakan sesuatu. Tentunya konsep dan kepercayaan kejolok tidak bisa diterima dalam iman Kristen.

\section{Seliwit}

Seliwit dalam bahasa Suku Dayak Punan Lisum artinya dalam mengerjakan sesuatu tidak akan selesai-selesai. Misalnya ini terjadi ketika seseorang ingin berladang atau menabur benih padi, apabila sudah memegang bibit jangan sampai membatalkan ikut kerja, atau ketika mau menebang pohon yang harusnya diselesaikan pada hari pertama kerja, namun lebih dari satu hari yang ditetapkan maka akan berdampak pekerjaan itu tidak akan selesai-selesai yang disebut seliwit (Beny, 2020; Inoq, 2020; Wenci, 2020; Yusuf, 2020). Untuk itu, dipercayai dalam kalangan Punan Lisum di hari pertama harus mengerjakannya dengan seimbang atau ketika ingin ikut bekerja tidak boleh membatalkan ketika sudah memegang alat untuk bekerja di tempat kerja karena akan terjadi seliwit (susah selesai). Jika diawali seperti yang dipercayai tersebut, maka itu dianggap penyebab dalam pekerjaan (berladang) susah selesai (seliwit). Tentunya pemahaman dan kepercayaan ini bagian dari mitos yang turun temurun dipercayai oleh masyarakat Suku Dayak Punan Lisum.

\section{Strategi Penaggulangan Sinkretisme Pada kepercayaan Suku Dayak Punan Lisum}

\section{Pelayanan Konseling Pastoral}

Berdasarkan hasil analisis data dan melalui pelayanan konseling pastoral bahwa sebanyak 16 orang (64\%) dari jumlah responden penelitian se- banyak 25 orang, yang menyatakan mereka memahami bahwa kepercayaan tentang mitos-mitos itu bertentangan dengan pengajan Iman Kristen, dan sebanyak 7 orang atau $28 \%$ masih menganggap ragu bahwa apa yang dipercayai itu bertentangan dengan iman Kristen dan sebanyak 2 orang atau 8\% menganggap pemahaman dan kepercayaannya tidak bertentangan dengan iman Kristen.

Pelayanan konseling pastoral mampu memberikan kontribusi dalam kehidupan iman masyarakat Suku Dayak Punan Lisum sebesar 84\%. Melalui konseling pastoral mereka juga dapat menghadapi dan mengatasi ketakutan terhadap mitos-mitos dan membuatnya memercayai Tuhan. Percaya kepada mitismitos dan membuat mereka merasakan ketakutan apabila melanggarnya dapat disebabkan pada aspek psikologis karena pemahaman yang berkembang turun temurun. Melalui konseling pastoral inilah pemahaman tentang imam Kristen dapat diperkuat dan diyakinkan akan kuasa Tuhan. Konseling pastoral yang berisi nasihat-nasih yang bersumber pada Firman Tuhan akan menenangkan dan menguatkan mereka menghadapi ketakutan karena mitos-mitos. Melalui konseling pastoral mereka dikuatkan dan diteguhkan pada iman percaya serta dimampukan mengatasi ketakutannya (Gintings, 2002).Konseling pastoral menjadi alat bagi gereja untuk membantu dalam mengatasi persoalan Kesehatan rohani jemaat (W. Gunawan, 2018). Melalui fungsi konseling pastoral mereka dibimbing, dituntun dan dikuatkan dalam menghadapi situasi tertentu, sehingga dibangun kehidupan spiritualitasnya (Wijayatsih, 2011).

Pelayanan konseling pastoral akan menjadi strategis dan efektif dalam memberikan pengertian tentang peristiwa-peristiwa yang dialami oleh Suku Dayak Punan Lisum. Melalui pelayanan ini mereka disadarkan dalam pengertian yang sederhana melalui upaya yang kontinue dan penuh kasih. Konseling sebagai upaya pendampingan yang dilakukan penuh kasih sebagai bentuk kepedulian secara khusus bagi yang sakit (Wijayatsih, 2011). Melalui konseling yang penuh kepedulian dan mereka disadarkan akan sakitnya membuat paradigmanya berubah. Bukan 
faktor apa yang dipercayai sebelumnya dalam kepercayaan Suku Dayak Punan Lisum sebelum menjadi Kristen, tetapi faktor-faktor kesehatan yang kurang diperhatikan. Konseling menjadi alat yang efektif bagi gereja dalam mengatasi kondisi kesehatan mental dan rohani jemaat. Melalui pelayanan inilah gereja melakukan pendampingan dan menyediakan bantuan, baik nasihat, doa, penguatan iman dan juga pengobatan maupun aspek sosial lainnya (W. Gunawan, 2018). Sebagai bagian dari pelayanan pastoral, melalui pelayanan ini gereja melakukan pendekatan menanamkan nilai-nilai firman Tuhan dalam memberikan bimbingan dan tuntunan, sehingga dapat bertumbuh dalam kehidupan spiritual (Widiyanto \& Susanto, 2020). Pelayanan ini yang dilakukan sesuai konteks secara kontinue dan penuh kesadaran akan sangat berdampak bagi pengubahan pola pikir, sehingga bisa menjadi salah satu strategi yang tepat dalam penanggulangan sinkretisme.

\section{Khotbah dan Pengajaran}

Hasil analisis data menunjukkan bahwa melalui khotbah atau pengajaran membuat mereka dapat memamahi pengajaran dan konsep iman Kristen. Hasil penelitian menunjukkan pelayanan khotbah dan pengajaran memberikan kontribusi sebanyak $72 \%$ dalam memberikan pemahaman yang benar tentang iman Kristen sehingga menjadi salah satu upaya dalam mengatasi sinkretisme di kalangan masyarakat Suku Dayak Punan Lisum. Sebanyak 20 orang atau $80 \%$ menyatakan bahwa mendengarkan khotbah membuat merekasadar danharus berharap hanya kepada Tuhan.

Khotbah dan pengajaransebagai salah satu strategi penanggulangan yang tepat bagi orang yang masih sangat mempertahankan sikap atau praktikpraktik sinkretisme. Tambunan (2010) menyatakan tujuan utama khotbah adalah membuat perubahan pada umat Allah melalui pengajaran kebenaran. Menurut Lebar (2006) yang dikuti Tafonao (2018a) bahwa jemaat memerlukan khotbah dan pengajaran. Dalam konteks inilah gembala yang diberikan tanggung jawab dan tugas mengajar dalam rangka pem- binaan iman jemaat (Tafonao, 2018a). Melalui kotbah dan pengajaran, jemaat dituntun untuk mengerti konsep iman Kristen dan dituntun dalam membangun dan mengokohkan iman percayanya di dalam Yesus Kristus. Melalui kotbah dan pengajaran jemaat dibimbing untuk hidup dekat dan mengimplementasikan iman percaya dalam kehi-dupan sehari-hari dengan tidak melakukan sinkretisme.

Gembala memiliki peran yang signifikan dalam menumbuhkembangkan jemaat dalam iman percayanya. Melalui pengajaran, gembala memberikan tuntunan sehingga jemaat bertumbuh dalam pengenalannya akan Kristus dan menampilkan sikap hidup yang mencerminkan nilai-nilai iman yang dipercayainya (Telaumbanua, 2019). Melalui khotbah dan pengajaran inilah, secara langsung jemaat mendapatkan pemahaman yang semestinya tentang iman Kristen. Pengajaran akan membuka cakrawala pemahaman yang sesungguhnya tentang Allah yang Mahakuasa dan yang telah dipercayai bagi masyarakat Suku Dayak Punan Lisum, sehingga diharapkan melalui khotbah dan pengajaran mereka dapat secara perlahan meninggalkan kepercayaan dan mitos yang telah turun-temurun disampaikan dalam cerita orang tua.

\section{Pemuridan}

Dari hasil analisis data menunjukkan bahwa pemuridan memberikan kontribusi sebanyak 92\% dalam menanamkan pengajaran tentang iman Kristen. Melalui pemuridan inilah mereka dibimbing, dituntun dan dapat mengalami perubahan pola pikir terhadap kepercayaan lamanya dan menaruh percaya kepada Tuhan dengan benar. Melalui pemuridan, secara khusus dalam mempelajari Alkitab mereka merasa secara perlahan dalam keterbatasannya, mulai memahami iman Kristen. Sebesar 96\% responden mengagap bahwa mempelajari Alkitab membuat mereka semakain memahami pengajaran iman Kristen dengan benar.

Melalui pemuridan yang menyadarakan mereka untuk gemar membaca Alkitab dalam meningkatkan pemahamannya mengenai iman Kristen. Pemuridan sebagai salah satu model pemuridan yang 
dapat diterapkan secara efektif tepat dalam pembinaan untuk pertumbuhan iman setiap orang Kristen (Panuntun \& Paramita, 2019).

Pemuridan menjadi metode yang efektif dalam mewujudkan pertumbuhan rohani jemaat. Melalui pemuridan jemaat dituntun, dibimbing dan dijadikan murid dengan melatih dirinya menjadi pribadi yang dapat mendemonstrasikan karakter yang berkenan kepada Kristus (A. Gunawan, 2020). Melalui pemuridan inilah masyarakat Suku Dayak Punan Lisum diajar, dijadikan murid, dibimbing dalam memahami konsep iman Kristen yang kemudian mereka dapat mengajar dan membimbing atau memuridkan yang lainnya. Menurut Hutagalung (2020) bahwa melalui pemuridan tidak hanya sekedar menjadikan orang percaya, melainkan bertumbuh dalam kehidupan rohani dan mampu menjadi saksi Kristus. Melalui strategi ini sangat membantu dalam menanamkan nilai-nilai iman Kristen yang benar dan kokoh, sehingga mampu menampilkan karakter Kristus dan mengikuti teladan-Nya.

Melalui pemuridan yang dilakukan secara berkesinambungan dan Alkitab menjadi sumber utama, akan membuat jemaat dapat ditanamkan pengertian, pemahaman dan wawasan tentang pokok iman Kristen. Di dalam Pemuridan diajarkan pokok doktrinal dan melatih melalui penerapan prinsip iman Kristen (Orles, 2020). Melalui pemuridan diharapkan jemaat memiliki iman percaya dalam pemahaman yang benar,sehingga membuatnya tidak melakukan sinkretisme dalam iman percayanya. Pemuridan ini yang harus dilakukan dengan komitmen yang kuat dan berkesinambungan dalam program gereja.

\section{Kelompok Doa}

Dari hasil analisis data menunjukkan bahwa kelompok doa sangat berperan penting dalam mengubah pemahaman dan menanamkan pengajaran iman Kristen. Melalui kelompok doa memberikan kontribusi sebanyak $60 \%$ dalam membuat mereka belajar membangun hubungan dengan Tuhan dan memercayai akan kuasa-Nya.
Kelompok doa sebagai salah satu strategi dalam membawa umat Tuhan, semakin dewasa di dalam Tuhan. Doa merupakan persekutuan dengan Allah (Sproul, 2002). Melalui kelompok doa menjadi sarana dalam mengatasi berbagai persoalan kehidupan keluarga yang mendatangkan pertobatan dan pendalaman iman percaya (Dewi, Tukan, Ngongo, \& Bele, 2020). Melalui kelompok doa seseorang akan menyediakan waktu untuk bersekutu dengan Tuhan, sehingga dapat bertumbuh dewasa di dalam Tuhan Yesus. Bahkan melalui kelompok doa, mengajarkan untuk tetap berharap hanya kepada Tuhan, dan senantiasa membangun relasi dan memercayai-Nya dengan sepenuhnya. Doa aka mengajarkan masyarakat Suku Dayak Punan Lisum memercayakan hidup sepenuhnya dan kuasa Tuhan yang melebihi kuasa apapun juga.

Interaksi akan terjalin secara baik ketika orang tua ada dalam suatu perkumpulan. Melalui perkumpulan tersebut menjadi sarana dalam berbagi pengalaman akan masa lalu dan media komunikasi yang efektif dalam menyampaikan suatu pesan. Kelompok doa atau persekutuan doa menjadi sarana komunikasi, sehingga terbangun hubungan antarpersonal yang baik (Missah, Walandouw, \& Londa, 2014). Hubungan interpersonal secara khusus diantara orang tua bisa menjadi media dalam melakukan tuntunan dan pembinaan iman, secara khusus ketika terjalin melalui persekutuan doa. Melalui ibadahibadah kelompok doa akan terjalin interaksi di antara jemaat secara para orang tua, sehingga bisa menjadi media yang efektif untuk menyampaikan pesan firman Tuhan, nasihat-nasihat dan pengalaman dalam perjalanan iman Kristen yang supranatural. Melalui kelompok doa ini akan menjadi efektif dalam membina Suku Dayak Punan Lisum mengenai iman percayanya kepada Tuhan Yesus Kristus, sehingga terhindar dari praktik sinkretisme.

\section{Pendidikan Keluarga}

Berdasarkan hasil analisis data dan melalui pelayanan konseling pastoral bahwa kepercayaan terhadap mitos pada masyarakat Suku Dayak Punan 
Lisum dikarenakan ajaran nenek moyang yang sangat kuat diyakini kebenarannya. Mereka mengikuti pola orang tua yang juga memercayai mitos dan memegang mitos tersebut dengan keyakinan yang kuat. Hasil analisis menunjukkan bahwa sebesar $72 \%$ menyatakan bahwa pemahaman dan kepercayaan terhadap mitos dikarenakan orang tua. Hasil ini menunjukkan bahwa perkembangan kepercayaan dalam diri masyarakat Suku Dayak Punan Lisum bersumber dari pendidikan dalam keluarga.

Strategi melalui pendidikan keluarga dapat mengubah pola pikir dan pemahaman generasi selanjutnya. Keseharian anak dan anggota keluarga dalam membangun komuniaksi di dalam rumah, maka peran orang tua melalui pendidikan keluarga sangatlah besar. Orang tua memiliki peran yang penting dan sangat kuat dalam membangun spiritual anak-anak melalui pendidikan dalam keluarga (Diana, 2019). Kehadiran kakek, nenek dan orang tua dalam kehidupan anak-anak atau generasi selanjutnya sangatlah berperan (Alex, 1988). Melalui perubahan kepercayaan pada diri orang tua (baik itu kakek, nenek, atau ayah dan ibu) akan berdampak pada pembinaan atau pendidikan tentang iman percaya di dalam keluarga. Orang tua yang sudah memiliki keyakinan yang kokoh dalam imannya kepada Yesus Kristus, maka dirinya akan memberikan pendidikan di dalam keluarnya sesuai dengan pemahaman dan kepercayaan imannya.

Pendidikan keluarga juga dilakukan dengan mengadakan mezbah kelaurga (Kristianto, 2006). Dalam konteks ini, keteladanan orang tua dengan menunjukkan komitmennya mengadakan mezbah keluarga pada waktu tertentu yang kontinue, seperti saat teduh di pagi hari sebelum melakukan aktivitas dalam keseharian. Kebaktian keluarga menjadi media mengajarkan iman Kristen oleh orang tua kepada anaknya, agar mereka bertumbuh dalam pemahaman yang benar dan kokoh iman, sehingga terhindar dari sinkretisme dalam perkambangan selanjutnya.

Pendidikan keluarga dapat dilakukan dengan memberikan nasihat kepada anak berupa Firman Tuhan yang dilakukan secara berulang-ulang (Gulo, 2017). Melalui nasehat tersebut anak dituntun untuk mengerti Firman Tuhan dan memercayainya sepenuh hatinya. Menjadi landasannya dalam bersikap dan berperilaku di dalam lingkungan sosialnya. Nasehat berulang-ulang diharapkan bisa menjadikan anak memiliki pemahaman yang semakin tajam dan kokoh (Ul. 6:7). Orang tua memiliki peran yang besar dan signifikan dalam pengembangan iman anak (Dewi et al., 2020). Penanaman iman yang kokoh agar pada masa dewasanya kelak tidak terjadi sinkretisme, maka dilakukan sejak dini, melalui pendidikan keluarga.

\section{Keteladanan Hidup}

Kepercayaan yang dimiliki oleh masyarakat Suku Dayak Punan Lisum bersumber pada orang tua dan keteladanannya yang diikuti oleh generasi selanjutnya. Secara khusus keteladanan dalam perilaku dan kepercayaannya mengenai mitos-mitos. Sebanyak 84\% responden menyatakan bahwa mereka dapat melawan mitos yang dipercayai dalam masyarakat Suku Dayak Punan Lisum apabila adanya orang tua yang memberikan keteladanan. Hasil ini menunjukkan bahwa perubahan kepercayaan sangat dipengaruhi keteladanan kepercayaan orang tua. Mereka dapat meninggalkan mitos-mitos kepercayaan dan beralih sepenuhnya pada iman Kristen apabila adanya orang tua yang memberikan keteladanannya.

Memberikan teladan dalan tingkah laku untuk tidak memercayai mitos yang dipercayai dalam kalangan Punan Lisum, dapat memberikan pandangan yang benar sesuai dengan iman Kristen.Mitos yang dipercayai justru menghambat pertumbuhan iman di dalam Tuhan karena hanya akan menanamkan rasa takut dan tidak percaya akan penyertaan Tuhan dalam kehidupan orang percaya. Menurut Situmorang (2020) keteladanan orang tua sangat memengaruhi perilaku dan karakter anak. Apabila orang tua memberikan keteladanan melalui pengajaran dan penanaman yang benar tentang iman percayanya serta berperilaku sesuai dengan imannya, maka akan berdampak pada peniruan oleh anak-anaknya. Pengembangan iman percaya anak, dimulai dari keluarga dengan memberikan perilaku teladan atau model bagi anak-anaknya (Dewi et al., 2020). 
Keteladanan dalam iman dan perilaku orang tua sangat berperan dalam mengubah pola pikir dan perilaku anak serta keseluruhan anggota keluarga. Keteladanan orang tua memiliki kekuatan yang besar dalam mengubah anak. Keteladanan menjadi media dalam mendidik dan mengajar anak secara khusus dalam iman percayanya kepada Tuhan Yesus Kristus. (Tafonao, 2018).

\section{KESIMPULAN}

Sinkretisme yang terjadi di dalam kehidupan iman percaya Suku Dayak Punan Lisum dikarenakan peralihan kepercayaan lama. Kepercayaan yang turun temurun dikarenakan pengajaran yang diberikan oleh orang tua berdasarkan tradisi. Sinkretisme yang memengaruhi dalam iman percaya dan keraguaannya akan kemahakuasaan Allah. Hasil penelitian ini me-

\section{DAFTAR RUJUKAN}

Alex, S. (1988). Pembinaan Anak Dalam Keluarga. Jakarta: BPK Gunung Mulia.

Away. (2020). Wawancara Pribadi. Desa Muara Belinau, 29 Februari.

Beny. (2020). Wawancara Pribadi. Desa Muara Belinau, 04 Maret.

Berkhof, L., \& Van Til, C. (2010). Dasar Pendidikan Kristen. Surabaya: Momentum.

Cahyadi, T. K. (2010). Benediktus XVI. Yogyakarta: Kanisius.

Dewi, A., Tukan, A. I. N., Ngongo, M. H. L., \& Bele, G. A. (2020). Mengembangkan Kualitas Hidup Keluarga Kristiani di Era Modern Melalui Persekutuan Doa Pasukris (CFC) Di Paroki Santa Maria Assumpta Keuskupan Agung Kupang. Prociding Seminar Lokal Ilmu Pendidikan Dan Teologi, Satu Hati Satu Tekat Untuk Penguatan Kelembagaan STIPAS KAK Dalam Era 4.o (Menyongsong Dies Natalis XIX), 76-83. Kupang: Sekolah Tinggi Pastoral Keuskupan Agung Kupang.

Diana, R. (2019). Prinsip Teologi Kristen Pendidikan Orang tua terhadap Anak di Era Revolusi Industri 4.0. BIA': Jurnal Teologi Dan nunjukkan terdapat sebelas bentuk sinkterisme dalam iman percaya Suku Dayak Punan Lisum yang meliputi kepercayaan tentang: Darau, Bulu sengangang, Dang, Salit atau Uwen, Petalo, Parit, Tengen, Ngoek, Petulang, Kejolok, dan Seliwit. Strategi yang tepat dalam upaya penaggulangan sinkretisme dengan melakukan pemuridan dan pelayanan konseling pastoral. Melalui pemuridan mereka diajar dan dimbimbing serta dimuridkan, sehingga akan memiliki pemahaman yang benar tentang iman Kristen, sehingga bisa meninggalkan atau terhindar dari sinkretisme. Melalui pelayanan konseling pastoral ketakutan atas mitos-mitos yang dipercayai dalam kepercayaan sebelumnya dapat diatasi, mereka dapat dikuatkan dan dibimbing untuk memercayai dan mempraktikkan iman percayanya serta hanya memercayai kuasa Tuhan yang melebihi kuasa apapun.

Pendidikan Kristen Kontekstual, 2(1), 27-39. https://doi.org/10.34307/b.v2i1.79

Erich, U. (2007). Menyingkap Tabir Praktek-Praktek Kuasa Kegelapan. Jakarta: Pustaka Sorgawi.

Gawa, E. C. S. (2020). Apologetika Kristen Tentang Kemahakuasaan Allah Serta Misi Apologetika Kristen. OSF Preprints.

Gintings, E. . (2002). Gembala Dan Konseling Pastoral. Yogyakarta: Yayasan Andi.

Gulo, S. (2017). Prinsip Pendidikan Agama Kristen Dalam Keluarga Bagi Keluarga Banua Niha Keriso Protestan (BNKP) Gunung Sitoli. Jurnal Global Edukasi, 3(3), 452-456.

Gunawan, A. (2020). Pemuridan Dan Kedewasaan Rohani. SOLA GRATIA: Jurnal Teologi Biblika Dan Praktika, 5(1), 1-17. https://doi.org/10.47596/solagratia.v5i1.52

Gunawan, W. (2018). Pastoral Konseling : Deskripsi Umum. Jurnal ABDIEL, 2(1), 85-104. https://doi.org/10.37368/ja.v2i1.63

Hutagalung, P. (2020). Pemuridan Sebagai Mandat Misi Menurut Matius 28:18-20. Pengarah: Jurnal Teologi Kristen, 2(1), 64-76. https://doi.org/10.36270/pengarah.v2i1.22 
Inoq. (2020). Wawancara Pribadi. Desa Muara Belinau, 25 Februari.

Jevi Nugraha. (2020, September). 5 Penyebab Ambeien yang Perlu Diwaspadai, Begini Cara Mengatasinya. Merdeka.Com.

Kobong, T. (2012). Iman Dan Kebudayaan. Jakarta: BPK Gunung Mulia.

Koentjaraningrat. (2002). Pengantar Ilmu Antropologi. Jakarta: PT. Rineka Cipta.

Kristianto, P. L. (2006). Prinsip dan Praktik Pendidikan Agma Kristen. Yogyakarta: Andi Offset.

Lebar, L. E. (2006). Education That Is Christian. Malang: Gandum Mas.

March, C. S., Siregar, D. C., Kharisma, S., Anita, P., \& Dewi, P. (2019). Analisis Kejadian QuasiLinear Convective System di Kupang ( Studi Kasus 10 Maret 2019 ) Analysis of QuasiLinear Convective System in Kupang. Seminar Nasional Penginderaan Jauh Ke-6 Tahun 2019, 230-236.

Marlena. (2020). Wawancara Pribadi. Desa Muara Belinau, 04 Maret.

Missah, C. L., Walandouw, A., \& Londa, J. F. (2014). Komunikasi Antar Pribadi Pada Orang Tua Lanjut Usia Di Panti Rumah Doa Kanaan Email: christylidyamissah@yahoo.com Latar belakang masalah Perlu ditelitinya bagaimana komunikasi antar pribadi pada orang tua lanjut usia sebab kom. Acta Diurna, 3(2), 53-61.

Mulyadi, R. M. (2019). "Elmu Anyar" Singkretisme Dalam Penyebaran Agama Kristen Di Jawa Barat Pada Abad Ke-19 Dan Awal Abad Ke- 20. Patanjala: Jurnal Penelitian Sejarah Dan Budaya, 11(2), 219-234. https://doi.org/10.30959/patanjala.v11i2.510

Noriati. (2020). Wawancara Pribadi. Desa Muara Belinau, 29 Februari.

Orles, O. (2020). Efektifitas Pemuridan KEKAL dalam Membimbing Gereja Menuju Kedewasaan Rohani. HUPERETES: Jurnal Teologi Dan Pendidikan Kristen, 1(2), 118129. https://doi.org/10.46817/huperetes.v1i2.22
Panuntun, D. F., \& Paramita, E. (2019). Hubungan pembelajaran Alkitab terhadap nilai-nilai (kelompok tumbuh bersama kontekstual). Gamaliel: Teologi Praktika, 1(2), 104-115. https://doi.org/https://doi.org/10.38052/gamalie 1.v1i2.30

Pdt. Ungau. (2020). Wawancara Pribadi. Tenggarong, 24 Maret.

Petemay. (2020). Wawancara Pribadi. Desa Muara Belinau, 29 Februari.

Rick, G. (1986). Praktek Sihir di Dalam Gereja. Jakarta: Yayasan Media Buana Indonesia.

Singgih, E. G. (2000). Berteologi dalam Konteks. Jakarta: BPK Gunung Mulia.

Situmorang, E. L. (2020). Pendidikan Agama Kristen Gereja Dan Keteladanan Orangtua Terhadap Pembentukan Karakter Anak Sekolah Minggu. https://doi.org/https://doi.org/10.31219/osf.io/6 gqt5

Spradley, J. P. (1979). The Ethnographic Interview. New York: Harcourt Brace Javanovich College Publishers.

Sproul, R. . (2002). Kebenaran-Kebenaran Dasar Iman Kristen. Malang: Literatur Saat.

Tafonao, T. (2018a). Peran Gembala Sidang Dalam Mengajar Dan Memotivasi Untuk Melayani Terhadap Pertumbuhan Rohani Pemuda. Evangelikal: Jurnal Teologi Injili Dan Pembinaan Warga Jemaat, 2(1), 36-49. Retrieved from https://journal.sttsimpson.ac.id/index.php/EJTI/ article/view/85

Tafonao, T. (2018b). Peran Pendidikan Agama Kristen dalam Keluarga terhadap Perilaku Anak. Edudikara: Jurnal Pendidikan Dan Pembelajaran, 3(2), 125.

Talan, Y. E. (2019). Mengkaji Bahaya Sinkretisme dalam Konteks Gereja. SESAWI: Jurnal Teologi Dan Pendidikan Kristen, 1(1), 43-54.

Tambunan, L. (2010). Khotbah dan Retorika. Jakarta: BPK Gunung Mulia.

Tanuwidjaja, S., \& Udau, S. (2020). Iman Kristen Dan Kebudayaan. Jurnal Teologi Kontekstual 
Indonesia,

$1(1)$,

$1-14$.

https://doi.org/10.46445/jtki.v1i1.299

Telaumbanua, A. (2019). Peran Gembala Sidang Sebagai Pendidik Dalam Pertumbuhan Rohani Jemaat. FIDEI: Jurnal Teologi Sistematika Dan Praktika, 2(2), 362-387. https://doi.org/10.34081/fidei.v2i2.45

Tong, S. (2000). Arsitek Jiwa 1. Jakarta: BPK Gunung Mulia.

Warren, W. W. (1992). Strategi Setan. Yogyakarta: Andi Offset.

Wenci. (2020). Wawancara Pribadi. Desa Muara Belinau, 04 Maret.

Widiyanto, M. A., \& Susanto, S. (2020). Pengaruh Pelayanan Kunjungan Pastoral Terhadap Pertumbuhan Rohani Jemaat. Evangelikal:
Jurnal Teologi Injili Dan Pembinaan Warga Jemaat, 4(1), 39-46. Retrieved from https://journal.sttsimpson.ac.id/index.php/EJTI/ article/view/214

Wijayatsih, H. (2011). Pendampingan dan Konseling Pastoral. Gema Teologi, Vol35nol/2(1/2), 1-7. Yendri, D., Wildian, \& Tiffany, A. (2017). Perencanaan Sistim Pendeteksi Kebakaran Rumah Penduduk Pada Saerah Perkotaan berbasis Mikrokontroler. PROSIDING SEMNASTEK 2017, 1-10. Fakultas Teknik Universitas Muhammadiyah Jakarta , 1-2 November 20171.

Yusuf. (2020). Wawancara Pribadi. Desa Muara Belinau, 04 Maret. 